\title{
MYELOID CELLS IN CEREBROSPINAL FLUID
}

\author{
BY
}

\section{A. I. SPRIGGS}

From the Division of Laboratories, United Oxford Hospitals

The cells of cerebrospinal fluid are usually examined in a Fuchs-Rosenthal chamber using a nuclear stain. By this means it is possible to distinguish between polymorphonuclear leucocytes and lymphocytes, but difficulties arise when other types of cell are predominant.

If films can be made of a quality comparable with that expected for haematological diagnosis, various other cell types are found. Besides neutrophil polymorphonuclears and small lymphocytes, one sees many cells of the lymphoid and plasma cell series, eosinophils, occasionally basophils, and a variety of monocytoid cells and macrophages (some of which may possibly be derived from the leptomeninges). For illustrations the reader is referred to Szécsi (1911), Rotstadt (1916), and Chalier and Étienne-Martin (1935). In rare cases tumour cells can be identified (Spriggs, 1954) or the abnormal cells of leukaemia (Spriggs and Boddington, 1958).

A surprising finding, which does not appear to have been previously described, is the presence of promyelocytes, myelocytes, and normoblasts in the cerebrospinal fluid of non-leukaemic cases. There are only some very doubtful instances in the literature. For example, Szécsi's (1911) coloured drawings include some granular cells referred to in the caption as lymphoidocytes; Plaut, Rehm, and Schottmüller (1913) mentioned a case in which granular " plasma " cells were present, the granules staining red-brown with Schridde's method (aniline acid fuchsin); and Rotstadt's (1916) coloured plate shows in row IV, Cell 7, something which might be a myelocyte, interpreted as " ? Mastzelle".

We have observed four cases in which myeloid cells occurred in the cerebrospinal fluid in conditions other than leukaemia, and brief case histories are given below. The method of preparing films is given by Spriggs and Boddington (1958).

\section{Case Reports}

Case 1.-A man of 54 was admitted to the Nuffield Department of Neurosurgery (Reg. No. 5238) with a history of "blackouts", right-sided weakness, and deteriorating vision. He was found to have a right

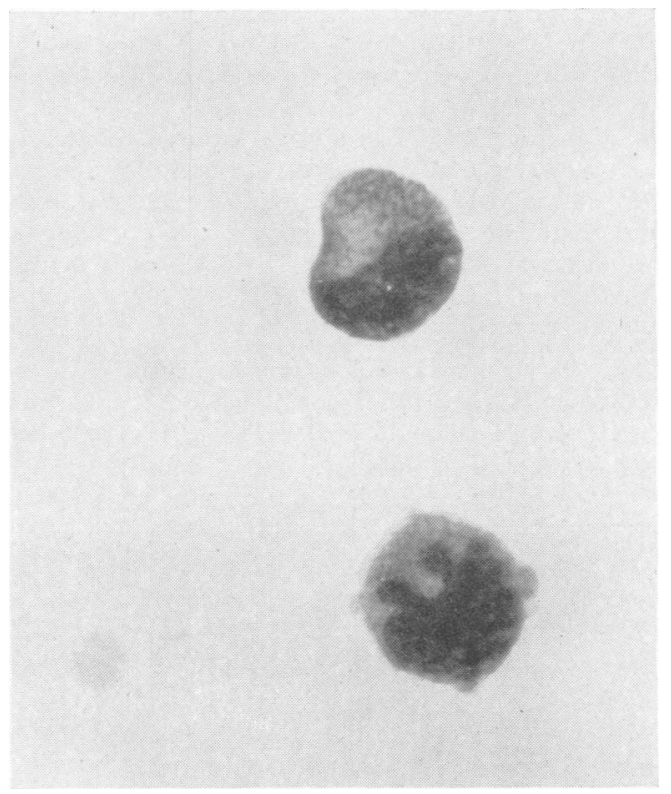

FIG. 1.-Case 1: The two white cells are (top) a neutrophil myelocyte and (bottom) a promyelocyte in a film of cerebrospinal fluid deposit $\times 1,180$ ).

hemiparesis. The lumbar cerebrospinal fluid was under a pressure of over $300 \mathrm{~mm}$. $\mathrm{H}_{2} \mathrm{O}$; the protein content was $250 \mathrm{mg}$. per $100 \mathrm{ml}$. The white cell count was $88 /$ c.mm. and the red cell count $96 / \mathrm{c} . \mathrm{mm}$. Because some unidentified cells were found in the counting chamber, a film was made (Fig. 1) and a differential white cell count was as follows: "Blast cells" $4 \%$, promyelocytes $7 \%$, myelocytes $25 \%$, band cells $17 \%$, segmented neutrophils $31 \%$, lymphocytes $14 \%$, monocytes $1 \%$, and normoblasts $1 \%$.

The patient's blood showed no abnormality. A left angiogram showed a large fronto-parietal lesion, and a meningioma weighing $99 \mathrm{~g}$. was removed a few days later. The patient's recovery was uneventful, and he was well four years later.

Case 2.-A boy aged 10 was admitted to the Nuffield Department of Neurosurgery (Reg. No. 179906) with paroxysmal headaches, vomiting, and diplopia. A cerebellar exploration revealed a cerebellar tumour, and 
he was treated by radiotherapy. Seven months after the operation he was readmitted with hemiparesis and hemianopia. A lumbar puncture was performed in the theatre as well as a puncture of the left ventricle and an aspiration biopsy. The tumour was a glioblastoma multiforme, and tumour cells were found in the left ventricular fluid. The lumbar cerebrospinal fluid had a protein content of over $1,000 \mathrm{mg}$. per $100 \mathrm{ml}$., no sugar, and a white cell count of $22 / \mathrm{c}$. mm. with 750 red cells $/ \mathrm{c} . \mathrm{mm}$. A differential count on a stained film was as follows:Promyelocytes $1 \%$, myelocytes (neutrophil $8 \%$, eosinophil 1\%), polymorphonuclears (neutrophil 35\%, eosinophil $1 \%$ ), lymphocytes $28 \%$, monocytes $24 \%$, normoblasts $1 \%$, unidentified $1 \%$.

No blood count was done at this time, but there was no reason to suspect leukaemia. The boy died a few days later.

At necropsy (P.M. No. 374/54) a large tumour was found involving the left frontal, parietal, and temporal lobes, and this had " seeded" in the dura and down the spinal cord. There was some opacity of the vertical and basal meninges, but histologically there was no evidence of invasion by tumour cells in these areas, and no myeloid tissue was found in the meninges.

Case 3.-A 69-year-old man (Reg. No. 4015) was admitted in cardiac failure to Cowley Road Hospital: he was incontinent and aphasic and had a right hemiparesis.

Cerebrospinal fluid obtained by lumbar puncture had a protein content of $30 \mathrm{mg}$. per $100 \mathrm{ml}$. and three white cells per c.mm. Films (Fig. 2) showed fewer than 100 identifiable cells, but a differential count on 80 cells was
FIG. 2.-Case 3: A neutrophil myelocyte in a film of cerebrospinal fluid deposit $(\times 1,180)$.

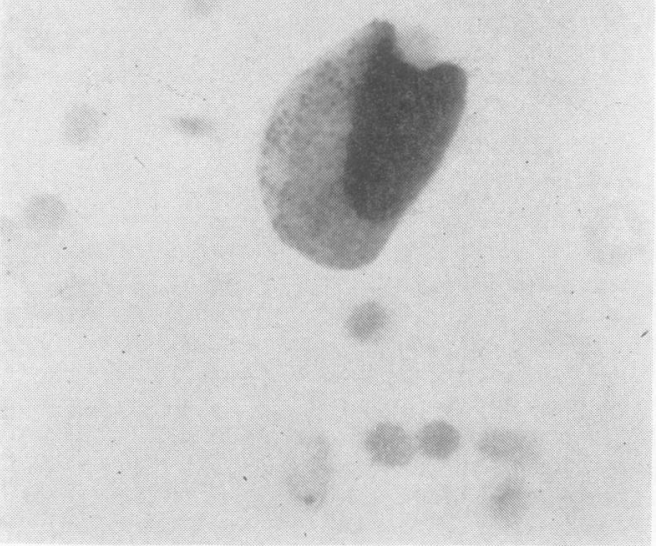

as follows:-Promyelocytes $5 \%$, myelocytes $26 \%$, neutrophil polymorphonuclears $32 \%$, lymphocytes $33 \%$, normoblasts $4 \%$.

A blood count and film showed no abnormality, and a second lumbar puncture 16 days after the first showed a normal fluid without myelocytes. The patient died seven

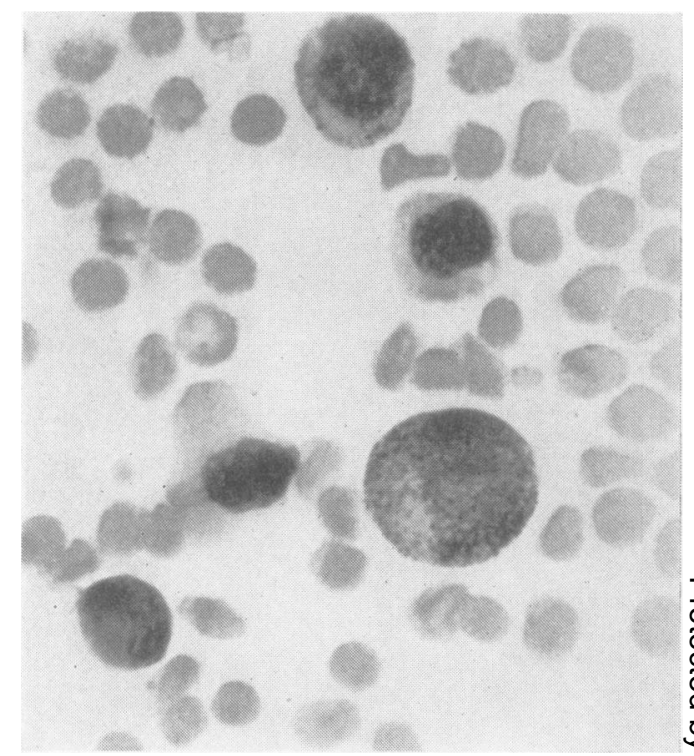

FIG. 3--Case 4: Field from a film of cerebrospinal fluid deposit showing immature granular cells and (at about 10 o'clock) a normoblast $(\times 1,180)$.

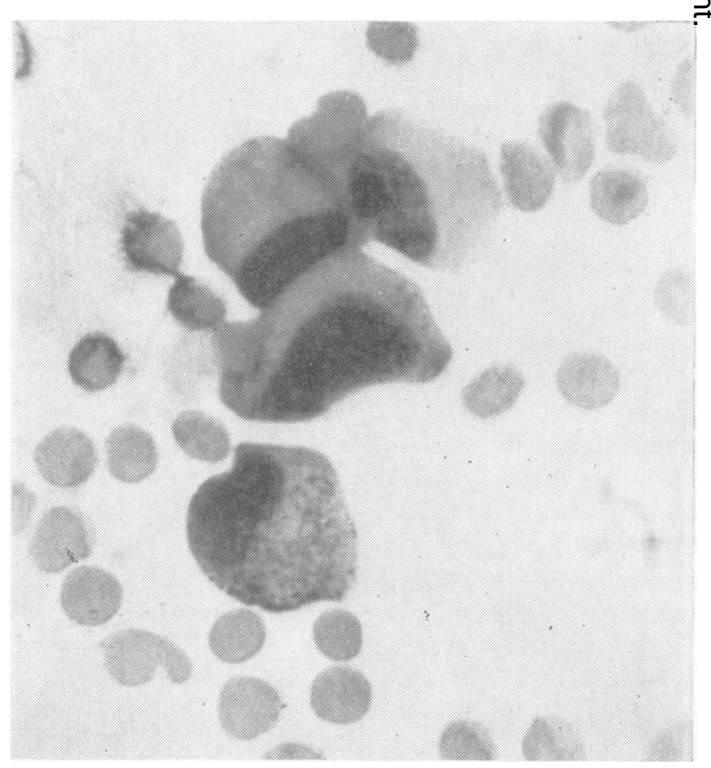

Fig. 4.-Case 4: Myelocytes and red cells in a film of cerebrospinal fluid deposit $(\times 1,180)$. 
weeks later and necropsy revealed multiple cerebral thromboses. No explanation for the abnormal findings in the cerebrospinal fluid was forthcoming.

Case 4.-A woman (Reg. No. 4280) of 85 was admitted to the Cowley Road Hospital with confusion, considered to be due to cerebral atherosclerosis, and hypertension. The haemoglobin level was $88 \%$ and a stained blood film showed no abnormality. A lumbar puncture was performed, and the cerebrospinal fluid had a protein content of $45 \mathrm{mg}$. per $100 \mathrm{ml}$., with 16 white cells and 650 red cells per c.mm. A differential count on a stained film of cerebrospinal fluid deposit (Figs. 3 and 4) showed:-Myeloblasts 1\%, promyelocytes $4 \%$, myelocytes $37 \%$ (neutrophil), polymorphonuclears (neutrophil $41 \%$, eosinophil $2 \%$ ), lymphocytes $7 \%$, monocytes $3 \%$, normoblasts (basophilic 3\%, polychromatic $2 \%$ ).

A second specimen of cerebrospinal fluid obtained 14 days later had a protein content of $45 \mathrm{mg}$. per $100 \mathrm{ml}$., 5 red cells per c.mm., and no white cells. The patient was discharged improved.

\section{Discussion}

In the four cases described, the cytological findings in the cerebrospinal fluid seemed to be clinically irrelevant, and in Cases 3 and 4 a second puncture produced normal cerebrospinal fluid without immature myeloid cells. It therefore seems most probable that the cells in question reached the cerebrospinal fluid accidentally as a result of the operator inadvertently puncturing a bone. The posterior surface of a lumbar vertebral body has only a very thin cortex (Fig. 5), and I have found, experimenting on a cadaver, that the marrow can be penetrated by this route with only a very slight sensation of resistance. A point in favour of this hypothesis was the presence in all four cases of moderate numbers of red cells. These are not usually present in such numbers in cases of leukaemia with raised cerebrospinal fluid cell counts (Spriggs and Boddington, 1958). Also the differential counts in the present series of cases are not improbable for small samples of normal bone marrow, allowing for the variations caused by centrifuging, making of very small smears, and counting of those cells which are sufficiently well preserved.

\section{Summary}

Four cases are described in which immature myeloid and erythroid cells were found in cerebro-

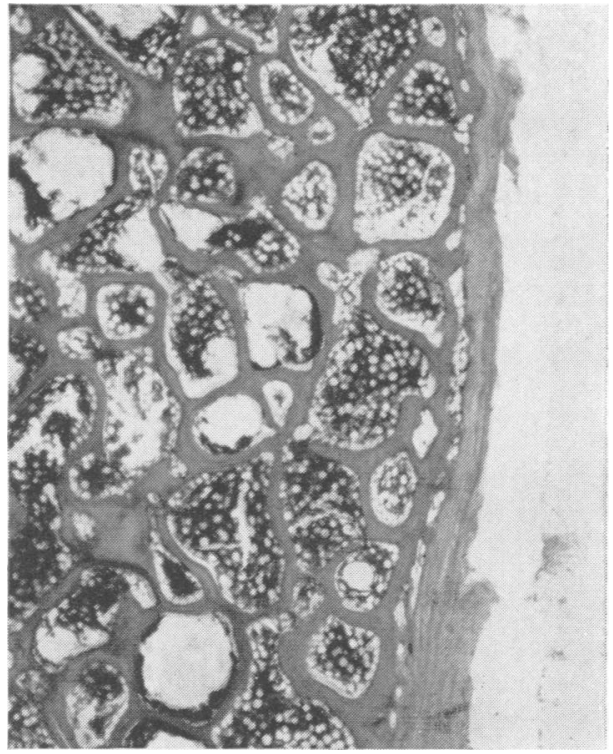

Fig. 5.-Transverse section of a lumbar vertebral body showing the posterior aspect. The cortex here is only about $0.2 \mathrm{~mm}$. thick ( $\times 14)$.

spinal fluid in the absence of any disease of the blood. In two cases, a second puncture produced normal fluid.

The presence of these cells is attributed to an accidental vertebral marrow puncture. The most probable site is a lumbar vertebral body, which has an extremely thin cortex on its posterior aspect.

I should like to thank Mr. Joe Pennybacker and Dr. P. D. Bedford for permission to publish details of their cases; Dr. D. Oppenheimer and Dr. D. B. Brownell for the pathological report on Case 2 and for helpful suggestions; and Dr. A. H. T. Robb-Smith for his advice and criticism.

\section{REFERENCES}

Chalier, J., and Étienne-Martin, P. (1935). Presse méd., 43, 1845. Plaut, F., Rehm, O., and Schottmüller, H. (1913). Leitfaden zur Untersuchung der Zerebrospinalffüssigkeit. Fischer, Jena.

Rotstadt, J. (1916). Z. ges. Neurol. Psychiat., 31, 228.

Spriggs, A. I. (1954). J. clin. Path., 7, 122.

- and Boddington, M. M. (1958). Brit. J. Haematol. In press. Szécsi, S. (1911). Z. ges. Neurol. Psychiat., 6, 537. 